\title{
Between Promise and Threat
}

\section{Antibiotics in Foods in West Germany 1950-1980}

\author{
Ulrike Thoms
}

\begin{abstract}
Zwischen Verrheißung und Bedrohung. Antibiotika in Nahrungsmitteln in Westdeutschland 1950-1980
Produktion und Verbrauch von Nahrungsmitteln sind traditionell mit weit reichenden Ängsten verknüpft. Bezogen diese sich in vormodernen Gesellschaften vorrangig auf eine ausreichende Versorgung, sind sie in der modernen Industriegesellschaft eher auf die Qualität der Nahrungsmittel gerichtet. In diesem Zusammenhang spielten in der Nachkriegszeit Antibiotika eine zentrale Rolle. Der Aufsatz stellt die Einführung der Antibiotika in die westdeutsche Veterinärmedizin, ihre frühe Diskussion als Konservierungsmittel und ihre wachsende Rolle als Wachstumsförderer dar. Vor dem Hintergrund einer zunehmend industrialisierten, auf Maximierung ausgerichteten Produktionspolitik werden die Rolle der Veterinäre, der Forschung und der wissenschaftlichen Experten sowie die Probleme der Regulierung des Antibiotikaeinsatzes in der Landwirtschaft diskutiert, die in die Entstehung eines unübersichtlichen grauen Marktes für Antibiotika und die Verlagerung ihres Einsatzes in die Therapie mündete. Besondere Aufmerksamkeit wird der Frage zugewandt, welche Rolle das Vertrauen und die Ängste der Verbraucher in diesem Prozess spielten.
\end{abstract}

Schlüsse/wörter: Nahrungsmittelproduktion, Antibiotika, Landwirtschaft, Wissenschaftliche Expertise, Veterinärmedizin, Medizin

Keywords: food production, antibiotics, agriculture, scientific experts, veterinary medicine, medicine

Food has always been connected with anxieties. Whereas in pre-modern times, people mainly struggled with the provision of enough food, in the late modern period the focus shifted to the quality of food. Due to the successes of modern agriculture and trade, Western countries no longer face the problem of food shortages and undernutrition, but are instead confronted with the problem of over-abundance and health-related problems like obesity (Scholliers 2008, Bruegel/Stanziani 2004, Fischler 2002). Even though people in industrialized countries expect to be able to buy as much food as they want, they are anxious about the purity of their foods, as illustrated by the increasing popularity of organic foods and the role of food scandals in the media. Many of the recent anxieties relate to contamination by poisonous substances or pharmaceuticals, and most are closely linked to the alienation of food production and consumption that has resulted from the processes of industrialization and 
globalization. These processes have involved the traditional production systems along with their central role of person-based trust relations, being replaced by an increasingly complex system of food production and retailing. Trust is a decisive tool for reducing such complexity in order to be able to participate in society. It does not abolish risks, but reduces them to uncertainties (Luhmann 1968).

In modern society, this trust is based on the existence of abstract expert systems, which monitor, control and regulate risks on the national level (Giddens 1995: 40-52), whereas in late modern society 'alimentalities' instead of nationalities are decisive. As Bildgårdt (2008) has argued, the food system has overcome national borders, and globalization has undermined the food production and marketing system as well as people's eating patterns. As crossnational food communities evolved, transnational systems of surveillance have been established and policy is based on and legitimated by social movements.

This paper discusses these changes using the example of antibiotics in West German agriculture and food technology between 1949 and 1980. I shall describe this period as the transitional phase from a modern, nation-centered food system to a late modern, highly industrialized transnational one. Food production increased enormously during this period, as did the variety of foods on offer even in the smallest shops. Large-scale production was established and the importance of global players increased. Antibiotics played an importantthough hitherto not fully acknowledged-role in this development, as they allowed for an intensification of farming and animal husbandry that had been unthinkable before. They were a major factor in the establishment of the late modern agro-industrial complex with its close relations between the spheres of the production, processing, marketing, and consumption of foods. As such, the topic of antibiotics leads us to ask how the risks of the new production tool were assessed, and to what extent the blurring of boundaries between the farm, the industry and veterinarians endangered the existing trust system. Moreover, this topic helps shed light on the roles played by social movements and expert systems in this process, and on whether new arrangements between producers, controllers and consumers of food were established.

I argue that antibiotics were a core element in the development of the modern food system, which was reconfigured under the new social, political and economic circumstances after World War II. Antibiotics have enforced the strong links between food and the medical system, for which questions of food, food spoilage and diseases caused by spoilt food had long played an important role. This paper will reconstruct this development and analyze the role antibiotics played in the two different expert spheres. Did antibiotics challenge the trust-based relation between the physician and his patient? How did their usage influence the relationship between food producers and consumers? Did they improve or undermine the trust placed in foods or in the experts involved? 


\section{Fears: Bacteria as Poisons}

Infections have been the most endangering illnesses for man for many ages. Around 1900, bacteriology and modern scientific hygiene were the leading medical disciplines. As effective treatments were lacking, infections were considered to be dangerous and life-threatening diseases (Berger 2009, Sarasin/Berger/Haenseler/Spörry 2006). Educational programs played on these deep-rooted fears and urged people to follow a clean and sober lifestyle. The education of housewives and mothers in cooking and kitchen hygiene was at the very heart of these efforts as food spoilage was a great concern, and especially dangerous for children in their first year of life. A basic change occurred only with the work of Alexander Fleming (1891-1955) and its later rediscovery by Ernest Boris Chain (1906-1976) and Howard Florey (1898-1968) during the Second World War. After antibiotics like tyrothricin and gramicidin had been found to be effective but toxic for humans if applied internally in the late 1930s (Bud 2007: 21), penicillin, which apparently did not have these negative side-effects, was deemed important for warfare. Chain and Florey worked to set up a large English-American joint venture with the help of the Rockefeller Foundation beginning in 1940. After they had managed to demonstrate its efficacy, large-scale production was set up (Adams 1991, Pieroth 1992, Wolf 1993, Forth/Gericke/Schenck 1997: 32-40, Bud 2007). After the end of the War, the antibiotics business boomed. Researchers were very efficient in identifying, isolating and patenting an enormous variety of different antibiotics. This development resulted in overproduction and declining prices, and in the search for new and promising markets, which were found in the sphere of agriculture. ${ }^{1}$

\section{Penicillin, Modernity and the Food Sphere}

Penicillin was the signum of modernity and the promise of a safe, germ-free world and meant the advent of the long-expected therapeutic revolution. Antibiotics appeared to be the man-made realization of the physician's dream, especially as only small amounts were needed, the product was a 'natural' one, and the side-effects were apparently limited. Moreover, penicillin research had-even before the Manhattan project-demonstrated the potency of modern, target-oriented, well-organized, collaborative, interdisciplinary bioscientific project research. This project nourished the belief that everything seemed possible in a set time frame, as long as enough money was available (Fig. 1).

Together with these factors, penicillin had much to do with the food sphere. Since ancient times, fungi and bacilli had been used as a means of 


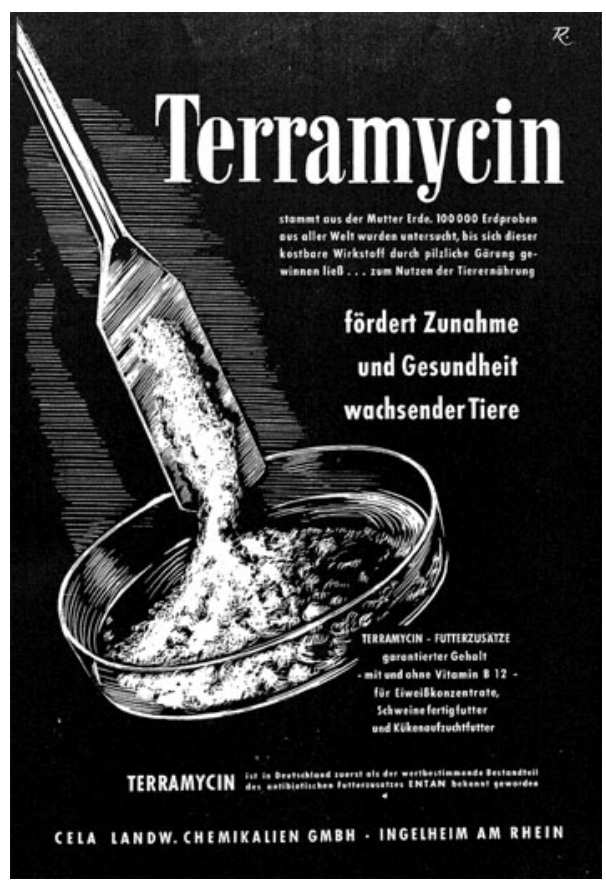

Fig. 1 Harmlessness by Naturality: Advertisement for Terramycin from $1953^{2}$

production in the food industry. Related microbiological knowledge was not confined to certain scientific disciplines but was shared between the food industry and medicine, as shown by the examples of Louis Pasteur and Konrad Bernhauer. In particular, milk and brewing science had accumulated such a bulk of practical and theoretical knowledge on germs and bacteria (Bud 1994, Marschall 2000) that their institutions were at the forefront of microbiological research. Until the middle of the $20^{\text {th }}$ century, microbiology and zymology were truly interdisciplinary fields.

One of the most distinguished researchers in this field was Konrad Bernhauer, a professor of biochemistry in Prague, whose publications on the methodology of zymology were important tools for both the beer brewers and the producers of penicillin. Similarly, the leading German institutions in biotechnology were not so much academic institutions at universities but research institutes of the food industry, such as the Institute of Brewery Science in Berlin and the Milk Research Institute in Kiel. Among the most distinguished researchers in this field, who were both active in the field of penicillin research, were Hermann Finck from the Institute of Brewery Science in Berlin and the veterinarian Andreas Lembke (Forth/Gericke/Schenck 1997: 32-40, Pieroth 1992) from the Milk Research Institute in Kiel.

The Milk Research Institute had collected strains of bacteria since its very beginnings, so that Lembke had a large number of them at hand and could use 
them for his own research (Shama/Reinarz 2002: 355). Like Hermann Finck, Lembke was a wanderer between the worlds of veterinary and human medicine and had degrees in both. Similar to Bernhauer, he worked on the production of foods like milk and cheese (Lembke 1940, 1943), but at the same time on the production of sulfonamides, penicillin and other antibiotics (Lembke/Ruska/Christophersen 1940) and their value for the treatment of humans. Lembke's biography illustrates quite nicely that disciplinary borders did not exist in microbiology at this time. Microbiology was a truly interdisciplinary field, and human medicine, veterinary scientists, the food and the pharmaceutical industry alike profited from the very same fundamental works, whose authors belonged to several scientific spheres. In 1945, Lembke founded his own Bacteriological Institute for Virus Research and Experimental Medicine in Eutin-Sielbeck near Kiel (Teuber/Milczewski 1990: 58), although he still retained his position at the Federal Institute for Milk Research. It was at his new institute that he developed Patulin between 1947 and 1949, for which he obtained a patent. ${ }^{3}$ Patulin was used against Bang infections (Brucellosis), which leads to miscarriages and at that time resulted in losses of about 250 million marks per year in Germany, 500 million dollars in the USA, 100 million francs in France and 19 million pounds in Great Britain. 4

Antibiotics first entered the food sphere as a drug for curing animal infections. One major aspect at stake was to increase hygiene in order to achieve successful risk control. Especially the milk industry had always portrayed itself as paying special attention to hygienic production conditions. Nevertheless, problems with milk as a transmitter of brucellosis and especially tuberculosis remained well into the $20^{\text {th }}$ century and called for new attention, since microbiologists like Lydia Rabinowitsch-Kempner from the RobertKoch-Institute in Berlin had shown that animal tuberculosis (bovine TB) was transmitted to humans via milk from diseased cows (Waddington 2010, Atkins 2000). Since the end of the $19^{\text {th }}$ century, the argument of hygiene was widely used by firms like, for example, Bolle from Berlin, which stressed their hygienic production methods and underlined that they had implemented modern methods of milk analysis within their firms, while the literature of the late $19^{\text {th }}$ and early $20^{\text {th }}$ century nourished distrust in small-and maybe damp-shops (Spiekermann 1993, Orland 2003). Lydia Rabinowisch-Kempner, in contrast, showed in the so-called milk-war of 1904 that Bolle's milk samples were only free of tubercle bacilli, because they had been manipulated by cooking the samples, while the sold milk was not treated at all. Together with her husband she pursued a lawsuit against Bolle which they finally won (Jaenicke 2009, Vogt 1997, Graffmann-Weschke 1999). In other words: Although industry claimed to have solved the problem, it remained part of the food production system. Such practices nourished fears and anxieties against the 'white poison' (Atkins 1992), as well as distrust in the producers, in practices to improve food quality, and in food in general. 
When antibiotics were introduced in the middle of the $20^{\text {th }}$ century, this appeared to be the key per se to this old problem, promising a safe and relatively simple solution. Robert Bud nicely described how the potential of antibiotics was demonstrated in a very impressive manner during the 1939/40 World Fair in New York. During the fair, an American milk company advertised its products under the heading, The Dairy World of Tomorrow. It displayed the so-called Rotolactor to the public, this being a modern, automatic milking parlour, which was supposed to help to produce hygienic milk that was untouched by human hands. Unfortunately, 16 of the 116 cows exhibited on this stand caught mastitis, a painful infection of the udder (Bud 2007: 166). The company was concerned and called for the microbiologist René Dubos (1901-1981), who treated the cows with the recently discovered gramicidin (Dubos/Hotchkiss 1940a, b). ${ }^{5}$ Three-quarters of the infected cows were saved (Bud 2007: 166-167). This demonstrated the healing power of the new drug with great effect and saved the reputation of the company. Moreover, it confirmed the soundness of the utopian dream of the Dairy World of Tomorrow.

From this moment onward, antibiotics played an important and ever growing role as new and powerful medicaments for the treatment of animals. In fact, they were applied in veterinary medicine before they were used to cure humans, because unpleasant side effects seemed to be acceptable in animals but not in humans. As such, they became a major factor in the rationalization of farms, especially with regard to cost-efficiency. Administering antibiotics to animals in order to fight communicable diseases-which had harmful effects for humans as well-meant making foods safer and trustworthy-and helped to increase production.

Veterinarians had been working on animal food regimes since the $19^{\text {th }}$ century, since with meat inspection they held an important position in the control of foods from animal origins. Consequently, the veterinary doctor became an indispensable part of the modern capitalistic, highly rationalized production system on farms and in the food processing industries. This development was reinforced by the veterinarian's increasing role in feeding science and reproductive medicine, which made the farm an important field and place of bioscientific research (Gaudilliére 2007).

German agriculture of the 1940s was far from the ideals of modernity as exhibited by the Rotolactor at the 1939/40 World Fair. Due to the leading principle of autarchy in the context of war, enormous efforts had been undertaken in Germany to increase agricultural production. The effects, however, were limited and, moreover, much agriculture had been destroyed during the War. The experiences of the second world war and the post-war period fostered deep-rooted concerns about the secure provision of food. In particular, meat was a scarce and expensive commodity from 1943 well into the late 1940s. A large number of people suffered from dystrophia, which was 
caused by a combination of an overall lack of calories and too little protein. These experiences nourished fears among a generation that was educated not to waste anything and to make full use of any available food, thus promoting the idea that food had to be handled and kept with great care in order not to lose it as a result of negligence or the lack of hygiene (Wildt 1994: 4-35, Brombach 2000: 175).

Against this background, the idea emerged of using a substance that kills harmful germs in order to prolong the shelf life of foods. Although penicillin remained a scarce and extreme commodity in Germany in this period, as early as 1949 an article was published in Germany which reported that penicillin had been used to preserve women's milk in a paediatric clinic (Linneweh 1949). At this time, the American, Canadian and English food industries used antibiotics (mainly aureomycin) with all kinds of food in order to prolong the shelf life of foods for another 7-10 days: in vegetables, cream fillings, but especially with fish, crabs and meat (Eichholtz 1956: 125, Partmann 1954, 1957). This was regarded as a "revolution in the field of food." 6 arious methods existed for applying the antibiotics: they were added to the water from which the ice for storing fish was made; they were injected in beef cattle shortly before slaughtering to extend the storage life of the meat; and pieces of beef, poultry and fish were dipped into a solution with antibiotics in order to kill germs on the surface (White-Stevens 1956: 104-122). After having been further developed at the end of the 1940s, this method was implemented during the 1950 s with the food conservation boom.

Pharmaceutical firms tried to get their share of this business and began to massively advertise for the use of antibiotics in fresh food. The American Cyanamid Company, for example, advertised in journals and organized conferences, one of which took place in 1956 in Vienna, where the firm presented aureomycin as a preservative for foods. The company's representative argued that especially meat and fish were "expensive commodities, in which losses play an important economic role, so that it is worth the price of a safety measure" (ibid.: 106). The economic relevance was obvious, as approximately a quarter of all fish deteriorated in the USA and Canada before it reached the consumer. ${ }^{7}$ And as the application facilitated transport, storage and sales of food, using this new method was welcomed enthusiastically. ${ }^{8}$ Antibiotics were also used to shorten the time of cooking during the conservation process and to lower the cooking temperature. ${ }^{9}$ This not only helped to improve the taste and consistency of the final product, but also saved precious time and energy and allowed for the rationalization of the production process.

Although such potentials were noticed around the globe, strong national differences remained in the use of the new methods. In contrast to the USA and Canada, German food experts hesitated to allow any additives, and even more so as some of the new substances had turned out to be toxic when ingested orally (ibid. 106, 124). Since toxicity was the major concern in 
discussions on food safety, this was a decisive element (Mossel 1955). Veterinarians like Hans-Jürgen Sinell were sceptical, especially when they found out that antibiotics are able to masque pathogenic bacteria in meat, thus disguising a health hazard (Sinell 1967). Research on this topic was continued, but the first West German food law regulations from 1958 already completely banned the use of antibiotics as food preservatives. It was simply argued that a sufficient number of approved and harmless preservatives such as benzoic and sorbic acid already existed, so that there was no need for another, possibly harmful substance (ibid.).

\section{Increasing Food Production to Save the World: The Use of Antibiotics as Growth Promoters}

The efforts to improve people's food have long been centered around animal protein. From the $19^{\text {th }}$ century onwards, scientists developed fantasies of nourishing humans and animals with artificial foods made from wastage, whereas ethical vegetarianism stressed the fact that many vegetable calories were 'wasted' on the production of meat when fed to animals and not directly to people. Although the German National Socialist State welcomed this rationalist model of food, it did not request citizens to become vegetarians (Thoms 2010b). The amount of available meat and animal products, however, decreased after 1939. Prior to these developments, research on the production of synthetic protein had become part of the economic policy of autarchy. Again, bacteriologists from the Institutes for Brewing Sciences, above all Hermann Fink, were at the forefront of this research. They managed to develop some products for human consumption, like Biosyn, which was tested in concentration camps (Jacobeit/Kopke 1999). To have synthetic and supposedly cheap proteins was of utmost importance in agriculture too, since protein is a limiting factor for animal growth. At the same time, it is the most expensive element in the animal feed and is thus decisive for the farmer's profit. Regarding this concern, yeast had already been used in animal feed since first world war (Lüers 1949: 64-68), and it seemed reasonable to feed the mycel (the leftovers from penicillin production) to chickens after the streptomycin had been extracted, especially since it is rich in vitamin B12, which had been recognized as growth-stimulating by a group of researchers in 1946 (Moore 1946: 437, Stokstad 1953). Accordingly, the agrarian economists were fascinated and worked on following up this finding.

The initial proof came from two American researchers, Stokstad and Jukes, who reported on their feeding experiments with aureomycin in chickens in April 1949 (Stokstad/Jukes 1949). In September 1949, their findings were confirmed by experiments conducted with pigs (Jukes 1950: 452). The 
outcome of these experiments was rather exciting for the veterinary doctors, as antibiotics allowed both a speeding up of meat production and a lowering of production costs at the same time. The literature boomed accordingly: during the 1960s, 100,000 research papers were published on the growth effects of antibiotics in animals. In accordance with the first findings of Stokstad and Jukes, they reported that progress was most rapid in the growth development of pigs, which would increase by 10-20 per cent. Moreover, they would need less feed and would suffer more seldomly from diarrhea, and, last but not least, their outer appearance would improve (Tangl 1959).

These impressive advantages were confirmed by detailed calculations. In 1957, H. Hegener from the Federal Milk Research Institute in Kiel demonstrated that the application of antibiotics would bring a surplus of between 17.50 and 27.50 marks per 100 kilogram of meat, depending on the sort of antibiotic used. Overall, 25 days of feeding were saved, so that the farmer could begin to raise the next generation earlier (Hegener 1953: 47-48). The argument of faster growth was economically convincing, although the reasons for these empirical findings were unclear and disputed at least until the 1960s. Some researchers cited the increase in appetite as the responsible factor, others the reduction of latent infections or the higher permeability of the intestinal mucosa. Even while scientific discussions on the effects of antibiotics continued, they were being widely used in animal husbandry to increase the output. The risks were played down and, instead, the economic advantages were stressed by veterinarians, who claimed they were able to control and steer the risks. It was they, not the farmers, who argued that "an agronomy like the German one cannot afford to neglect such an economic advantage, which stands in opposition to only vague conclusions by analogy and assumptions" (Brüggemann 1957).

These developments were strongly linked to the Americanization of West Germany (Krige 2006, Zeitlin/Herrigel 2000, Nolan 1994, Bjarnar/Kipping 1998, Rutschky 2004). The Marshall Plan and the Technical Assistance Program were oriented towards a transfer of the American model to Western Germany, through increasing productivity and efficiency by technical progress and by scaling up the size of farms for the sake of a rationalization of production. The conditions of American farms, with their average size of 87.4 hectares in 1950, were hardly comparable to German farms, which had only 8.06 hectares on average. Although the German farm size more than doubled to 18.17 hectares in 1990, their American counterparts had by this time grown to 198 hectares. ${ }^{10}$ The main reason for the German increase of farm size was an enormous intensification of output, which made a massive increase of meat consumption per capita possible in the Federal Republic of Germany: from 36 to 102 kilogram between 1950 and 1974/75. In particular, poultry-formerly a luxury food-became an everyday and cheap food item. Between 1950 and 1974/75, its consumption boosted from 1.2 to 8.8 kilogram (Teuteberg 1986: 237) while food prices increased only moderately. 
The motivation to raise food production by any and all means was further increased by the background of reports on the world food situation. The World Health Organization (WHO) and the Club of Rome published extensive studies on nutritional deficiencies and food-related diseases as a reason for the death of hundreds of thousands of people in the so-called under-developed countries of the "Third World," especially among children. Prognoses painted a horrifying picture of the future development of the world's nutritional situation (Malycha/Thoms 2009, Uekötter 2009). Research showed that the hunger diseases, especially kwashiorkor, occurring in large parts of Africa, were basically the same phenomena that had taken place during and shortly after the second world war, and would especially endanger the physical and mental development of children. The WHO report from 1962 stressed "that the world scarcity of protein makes it necessary to conserve and utilize meat supplies to the fullest possible extent" (Pearson 1962). Two years later, the Food and Agricultural Organisation (FAO) started its "Freedom from Hunger" campaign, in which numerous well-known German nutritional scientists were involved (Cremer 1962, Staples 2003). Only a few years later, the report of the Club of Rome presented the extent of the ecological and social catastrophe to come, thereby underlining the relevance of the WHO campaigns (Meadows 1972).

These prognoses caused fears over how a supply of food sufficient for the enormously growing world population could be achieved. Moreover, they posed the question of the modernization of agriculture, which was seen as a general prerequisite to overcoming hunger. Referring to the use of antibiotics in agriculture, Brüggemann argued: "The success justifies the measures (i.e. the application of medicated feeds) and as long as disadvantages of any kind cannot be proved we can make use of the agents [Wirkstoffe], as another means of keeping our animals healthy and to improve their performance" (Brüggemann 1957: 15). Overall, the advantages seemed to dominate, at least as long as the research discussion was centered on classical questions of toxicity and residues. Respective investigations proved that the organs and meat of treated and slaughtered animals showed almost no changes, in contrast to the meat of animals that were given hormones (ibid. 1957: 15).

\section{The Production of Distrust by the Antimodernist, Ecological and Consumer Movement}

The possible negative effects of antibiotics were used as a central theme by the right-wing life reformers and the emerging ecology and consumer's movement. The representatives of these groups pointed towards the potential of antibiotics to cause severe allergies, as anaphylactic shocks had 
been observed among some patients. In general, they stressed the need for the naturalness of ingested foods and thus demanded that no additives be used (Zinzius 1954). For a long time, they had accepted the idea of dysbacteria as the cause of diseases, arguing that diseases would result from disturbances of the inner equilibrium caused by imbalances within the bacterial flora of the intestines. For them, the destruction of bacteria by antibiotics was a medical malpractice.

One of the most active critics of the increasing use of antibiotics was the newly founded Gesellschaft für Vitalstoff-Lehre. This society held yearly assemblies, in which resolutions on different topics were passed. It is not by accident that the first of these resolutions from 1955 was on antibiotics and asked for more research. ${ }^{11}$ Resolution No. 18 asked for a means for constricting the administration of antibiotics, since they would destroy the body's natural immune system, weaken the resistance against infections, and thus make the body receptive to possible future diseases. ${ }^{12}$ Many of their claims, like for example the harmful influence of antibiotics on the bacterial flora of the intestines and the receptivity for infections after antibiotic treatment, have since been proven. At that time, however, both the claims and the ways in which they were formulated were considered to be odd, over-sceptical, disrespectful and backward (Cremer 1957). The reason for this may be that articles in the society's journal were quite polemic and painted horrifying pictures of the consequences of taking antibiotics and other chemical substances (compare e.g. Schweigart 1956).

Nevertheless, critique spread and was increasingly supported by consumer organizations. These basically followed the argument that antibiotics and other additives might worsen the negative influences of civilization on the human organism. They took the existence of residues for granted, while they demanded that every unnecessary manipulation that was rooted in profit concerns should be eradicated. The only problem was that no effective method of analysis existed. Moreover, they fully acknowledged the difficult situation of West German farmers who had to face the fierce competition of imported and cheaper meat from countries like the USA, where growth promoters and other drugs that were forbidden in the Federal German Republic were widely used. Thus, they argued that the real reasons for this problem were not genuine German problems, but were rather imposed by the international meat trade. ${ }^{13}$ This tendency continued until the end of the 1960s, while consumer organizations hoped for the cooperation of the Health and Agricultural Ministry. Over time, they realized that not only antibiotics, but also hormones and thyrostatics were administered to animals. The public press often did not differentiate between these drugs, but discussed them under the broad term "additives," emphasizing the question of acceptable doses, which is totally irrelevant in the case of antibiotics. 


\section{The Role of Scientific Experts. Governing the German Risk Discourse}

Food scientists and health officers followed a somewhat purist position. Since the $19^{\text {th }}$ century they had argued with the consumer's expectation that fresh food should not contain any additives. In line with this tradition, the new food law of 1958 prohibited the use of antibiotics as a food additive. The committee justified its claim by stating that the use of antibiotics caused serious medical concerns, and that they might cause allergies that were possibly harmful to the microbiological flora of the intestines. This, in turn, could lead to the development of resistant strains, which would eventually be resistant to any treatment (Höfer/ Juckenack/Nüse 1961: 84). At the same time, however, the orthodox natural scientists in the state institutions strongly criticized the emotionalization of the discussion. They spoke of tales of atrocities and claimed that problems of the natural sciences and of toxicology could only be solved on the basis of research and by scientific experiments. Above all, they questioned the oppositions of what is considered 'natural' and 'synthetic,' claiming that this leads to philosophical discussions. They pointed out that some of the most toxic substances, e.g. Coumarin, could not be fabricated by man but occurred in nature, and that therefore the opposition between natural and synthetic is irrelevant to making judgements about the riskiness of a substance (Lang 1957, Kraut 1959).

The generation holding the important positions in the Federal Research Institute, however, had made their academic careers under the National Socialist Regime, when food science had to help achieve the aim of autarchy by increasing production. Even when certain substances were regarded as hazardous, they were accepted in order to secure sufficient provisions for the people (Sperling 2011). Under this system, the consumer's position was very weak. Consumer organizations did not exist and consumers were manipulated to eat according to the amount of production. Although the Nazis argued that the consumer would expect fresh food without additives, in practice they abandoned their reformist viewpoint for the sake of public opinion, war economy and autarchy (ibd.). The likes and dislikes of the people were taken into account for strategic reasons (Drews 2002), but public discussions on food matters were definitely not allowed, and critical and independent movements like vegetarianism were silenced and forbidden (Thoms 2010b). It was assumed (or pretended) that consumers would only be confused by different scientific opinions on the issues of food additives and poisons. Accordingly, the state developed its nutrition policy in close contact not only with scientists, but also with the corporatist organizations of agriculture and the food industry, which argued for their profits. As a result, the use of preservatives like crotonic acid, calcium propionate and monochloroacetic acid in the food industry was allowed, even though the existence of associated risks was known and acknowledged (Sperling 2011: 260-268). 
This perspective persisted with the political changes after 1945, especially since the scientists retained their positions in the research institutions (Thoms 2006). Scientists and state institutions were horrified that the German housewife would read "poison" if "chemical preservative" was printed on a package. ${ }^{14}$ This was mainly due to the press work of life reformers and publicists such as Curt Lenzner who had published his book Gift in der Nahrung (Poison in Food) in 1931. Lenzner's book sold fairly well, with a second edition following as early as 1933 and a third one in 1956. This book and its perspective shaped the discussion during these years, and it was mentioned whenever poisonous or risky substances in food were discussed.

The Commission for the Examination of Chemical Food Preservation (Kommission zur Prüfung der chemischen Lebensmittelkonservierung) was set up as an expert committee on food additives at the German Research Association (Deutsche Forschungsgemeinschaft, DFG). It rejected the preservation of fresh food such as meat and fish with additives as well as the use of any antibiotics, stating that they could cause serious medical problems because they might lead to allergies that could be harmful to the microbiological flora of the intestines, and because their use might lead to the development of strains resistant to any treatment (Höfer/Juckenack/Nüse 1961: 84). Therefore, the food law of 1958 prohibited the use of any food additives, if these were not on the list of approved additives. This brought a remarkable change in perspective. Antibiotics were no longer seen as possibly harmful or toxic substances; instead, the direct and indirect consequences of their excessive use were recognized as the real threat.

Following the former policy of governmental information control, the food chemists as well as the members of the said commission did not take part in public or public scientific discussions. Probably as a result of their experiences with an intense public discussion on hexamethylenetetramine (Stoff 2009) and the intensity of the recent public discussions on food, they dealt with the issue of food additives in an utterly quiet manner. The above mentioned commissions of the DFG only published Mitteilungen, that is announcements, which consisted of strict and relatively short statements on certain topics (Mergenthaler 1955). Reports on the discussions within the commission were not published at all, and the members themselves were rather reluctant to publish on the issue or on the work of the commission. Even when the German weekly newspaper Der Spiegel interviewed Walter Souci, the director of the German Research Institution for Food Chemistry, he used this opportunity merely to announce, rather than to explain his position. ${ }^{15}$

A major problem in the development of an effective food legislation was the lack of control. Following a German food law tradition, the law provided only a general outline, but no positive definitions of foods and their quality. Instead, it was stated that these would be regulated by decrees still to be worked out. This, however, took a long time and once the regulations were 
released they were found to be outdated, incomplete and contradictory. This practice handicapped criminal prosecution in particular, since the lack of clear and strict regulations facilitated food fraud. ${ }^{16}$

Food questions should have been of concern to doctors, but although doctors were informed on the legislation on the new food law and regulatory statutes, ${ }^{17}$ they did not appear to be very interested in this issue. Their journals did not document any discussion, nor did they register the developments in food production. In 1956, a publication of a medical doctor spoke of the lethargy of his colleagues with regard to this problem. It stressed that the female members of parliament had been the ones who asked for legislative measures. Implicitly, it assumed that these women were speaking on behalf of housewives, who were still regarded as responsible for the physical well-being of their families (Eichholtz 1956: Einleitung). It was only in 1958 that the German Medical Association (Bundesärztekammer) held a meeting on antibiotics, but no extensive report on this meeting was ever published. ${ }^{18}$ Although doctors recognized allergies and resistancies as problems to come, the medical boards were swayed by the harmless nature of antibiotics in animals, which were important as a source of food for humans. Consequently, it was only during the late 1960s that the work of several English committees and the ongoing American discussion on this issue was acknowledged, and that a more intense discussion began. Overall, it was expected that the pharmaceutical industrywith which the doctors held strong relations-would solve the problem. ${ }^{19}$

Less attention was paid to the use of antibiotics as drugs in animals, even though the DFG commission discussed antibiotics as food additives. Development was hampered by the classical toxicological view that the dosage makes the poison, which dominated the discussion about the risks associated with antibiotics. According to this view, it seemed unimaginable that the low prophylactic doses of 10-20 milligram antibiotics in feed would be harmful as therapeutic doses were two or three times higher and had no negative consequences at all. In addition, antibiotics were regarded as harmless because they would be excreted from the body relatively quickly and any residues would eventually be destroyed by cooking. In medical practice, antibiotics were trusted substances with positive, quick and life-saving effects, and as long as the number of new antibiotics steadily increased, even the problem of resistancies was almost nonexistent.

The focus shifted only over time, motivated by various developments. First of all, when the speed of finding new antibiotics decreased, the research costs exploded. It became obvious that the arsenal of different kinds of antibiotics was limited. In agriculture and the food industry, perceptions changed as milk researchers and veterinarians increasingly observed the development of resistancies in bacteria which cause mastitis. At first, the dimension of this resistance was not fully recognized; studies concentrated on resistance in humans and disregarded the influence of the so-called low nutritive doses 
(Knothe 1967: 28-29). During the 1950s, influential scientists still argued that resistancies would not occur in animals (Brüggemann 1954/1955, Freerksen 1956). From the beginning of the 1960s onwards, however, maintaining this position was no longer possible. Enquiries from 1962 to 1967 clearly showed, for example, that the resistance of streptococci against penicillin had risen to 70 per cent and that this was due to unspecific treatment of mastitis (Weight/ Kramer 1968). Nevertheless, the connection with the impact of medicated feeds was still not commonly acknowledged.

The second factor was the public discussion about the marketing practices of the pharmaceutical industry, which began in the mid-1960s. Very much inspired by Ruth Harrison's book, Animal Machines, a more critical view slowly emerged, and the close connections between the pharmaceutical industry, veterinarians, agriculture and the food industry were critically discussed (Harrison 1965). German animal welfare activists and leftist groups of ecologists took up Harrison's arguments and campaigned for drug-free stables.

Finally, the butchers and meat processing firms became more critical as well. West German butchers took (and still take) pride in their craftsmanship, which obliged them to offer quality products to their clients whom they knew personally from the encounters in their shops. As letters from butchers to editors of professional journals clearly show, clients were becoming increasingly critical and asked for meat that was free of antibiotics, hormones and other medicaments. Stating that "the problem of antibiotics is not the problem of butchers, but of farmers and breeders," they refused to take any responsibility for contaminated meat. ${ }^{20}$

\section{Dark Secrets: The Alliance Between Veterinarians, Agriculture and the State}

In their replies to the complaints of butchers and consumers, representatives of the West German Agricultural Ministry and of the Health Ministry stressed the harmlessness of certain doses of the additives and pointed to the regulations of the Food Law. The only problem was that the large and still-expanding food market was regulated by old contradictory laws. In fact, three laws were concerned as the medicated feed touched upon problems of animal feeding, human food and drug legislation. All of the laws in question were outdated when antibiotics were introduced in agriculture. The feed law dated back to 1926, the food law to 1927, and the drug law to 1941, when antibiotics were not yet known. Moreover, there was regulatory chaos as food control, which is decisive for law observance, is the task of the federal states. The states had released decrees that regulated different aspects and were partly contradictory. In fact, effective control was not possible at all (Barke 1954). Violation was 
commonplace as breaking the laws was punished with ridiculously low fines that were totally disproportionate to the profits from the illegal sale of forbidden substances. The production cost of feeds with thyrostatics, for example, was at four marks per feed ration, but these feeds were sold for 44 marks in 1968. A lawsuit from the same year sentenced a seller of these illegal growth promoters to a fine of only 3,000 marks (Wolff 1968). Accordingly, a grey market with a turnover of about 40-50 million marks per year developed in which veterinarians played an important role (Brühann 1971: 168).

A central problem was the unclear status of the medicated feeds, which contained antibiotics as growth promoters: should they be classified as feeds or drugs? If one regarded them as feeds, as the feed industry postulated, they would fall under the feed law. In that case, the regulations of the German Agricultural Society (Deutsche Landwirtschaftsgesellschaft) would be important. This society provided scientific advice and had developed standards for feeds. In order to improve the quality of feeds, it had introduced a quality label for feeds (Münzberg 1954, Behm/Jäger 1955). This quality label is awarded to firms that follow trade customs and have the required production plants and experienced personnel. They must carry out quality controls and their products have to be proven to be satisfactory in practice. ${ }^{21}$

The feed regulation (Futtermittelanordnung) from October 24, 1951 stipulated that all feed had to be registered at the Federal Ministry of Food, Agriculture and Forestry (Bundesministerium für Ernährung, Landwirtschaft und Forsten) and that it had to fulfill certain quality requirements, which were to be declared on the package and which would be tested (Entel 1970). These regulations were thought to protect the buyers against economic disadvantages as well as to protect the health of the animals. ${ }^{22}$

The law, however, allowed arbitrariness and different interpretations. This decree served the two purposes of making available means for the rationalization of agriculture and of safeguarding the consumer's health. Thus, the effect of measures would rely on where and how the lines were drawn, and on how much weight would be given to economic aspects. Since it was possible to have special permits awarded by the Ministry of Food, Agriculture and Forestry, there were loopholes that could limit the effect of this measure. The choice of whether or not to make use of antibiotics for the sake of profits was still left to the farmers. Therefore, the agrarian lobby welcomed the new law warmly with the words: "Our new drug law contains something very wonderful that is a democratic-liberal view, as it meets the principles of our economic ideas. We should take care not to dilute this thought in its proper contents as we tend to regulate everything" (Kaemmerer 1967: 9).

This situation was found to be unsatisfactory, however, so that two supplements to the feed law were released in 1966. They were centered around the veterinarians as gatekeepers and strengthened their role in this game even further. Basically, veterinarians were obliged to follow the same drug law as 
physicians. In fact, both used the same tests to determine diseases and similar substances to cure their patients, and both were obliged to not harm them (nil nocere). Nevertheless, the veterinarian's responsibility was not limited to the health of the animals. He was also responsible for human health, as he held a strong position in the food control system, where he decided on the quality of meat, milk and all the products that were made from them. State organs simply expected that veterinarians-like doctors-would carry out their duties appropriately. They expected that this food control system would manage to detect the misuse and especially leftovers of antibiotics in feed.

The veterinary doctors were (and still are), however, integrated into the economic system of feed production and thus experienced conflicts between medicine and the market. In contrast to the human physician, who cannot sell but only prescribe drugs, which the patient then obtains from the pharmacy, the veterinarians were and still are allowed to dispense (that is, sell) drugs. In fact, they manufactured, prescribed and sold drugs all at once. At the same time as the veterinarian as a doctor had to steer and control the use of drugs, it was widely accepted that the veterinarian also had to seek and secure his share of the market, for example by cooperation with the feed industry or by the foundation of an own production firm (Brühann 1971). Thus, his task was not only to cure sick animals, but to help maximize output by administering substances, which were used as drugs. In the long run, the Ministry of Food, Agriculture and Forestry realized that this in-between agreement was not sustainable, as drugs got into lay people's hands and farmers would use them too liberally. Nevertheless, the German state did not stop the alliance of farmers with veterinarians and the pharmaceutical industry, since German agricultural policy followed the general line of increasing the 'performance' of the livestock (Brüggemann 1954/1955). Agricultural associations and the Ministry for Food and Agriculture pointed to the economic constraints of farmers, which made the use of pharmaceutical products necessary. And even though federal agencies like the Federal Health Office (Bundesgesundheitsamt) criticized the use of pharmaceutical substances, their representatives considered it to be a justified necessity. They asked for farmers' assumed need to use pharmaceuticals to be accepted as a fact, "which even the critiques of such a development have to acknowledge." 23 There was no way back in this system; the only question was how to control the use of drugs like antibiotics.

The feed and pharmaceutical industries were of course central actors in this game. Both profited significantly from the politics of increasing productivity using all means. Sales figures of feed additives in the USA had grown from 55-60 millions dollars in 1950 to 142 million dollars in 1965. From the overall production of 2 million pounds of antibiotics, 490,000 pounds were used in livestock feed. By 1960, this amount had increased to 1.2 million pounds and to 25 million pounds in 1990 (Boyd 2001: 648). In Germany, the industrialization of agriculture began somewhat later, but the use of ready, industrially mixed 
feeds grew rapidly: from 500,000 tons in 1949 to 7.7 million tons in 1967 (Entel 1970). This means that their use grew three times as much as the number of farm animals (pigs, cattle, sheep, poultry), which increased from 32.6 million to 117.2 million in this period. ${ }^{24}$ The effects on the increase of meat production were immense. In 1950, meat production had only reached 87 per cent of the pre-war amount, but only seven years later it was at 134 per cent and kept climbing up to 162 per cent in 1962/63. Even more remarkable were the gains in poultry production, where modern methods of industrialized agriculture were taken over from the USA. The poultry breeder Heinz Lohmann serves as a particularly good example for the development of the modern agribusiness. Lohmann had owned a fish meal factory since 1932 and a freezing plant since 1938. After a visit to the USA, where he studied poultry breeding, he set up the production of broilers on an industrial scale in 1954. Over the years, he built up an integrated complex of firms, which produced the feeds and the drugs, bred the chicken, brought them up, fattened them, slaughtered them, processed their meat into several products like breast and chicken sausages, and finally distributed them via a large sales organization. ${ }^{25}$

Nationwide, the production of poultry meat doubled and again almost tripled to reach 334,000 tons in $1970 .{ }^{26}$ This went hand in hand with an increase of the average market weight of a broiler from 3 to about 3.5 kilogram, while the feed conversion and the number of days a broiler needed to reach market weight almost halved from 95 days in 1945 to 56 in 1975, and reduced by another nine days by 1995 (Boyd 2001: 637). Antibiotics were not the only reason for this increase, for which breeding science was also responsible, which achieved an overproportional growth of the white breast meat and the loss of satiety feeling. In this system, antibiotics played their role as growth promoters, but just as important was their role in the control of diseases, which spread easily in very crowded and closely populated stables. Ironically enough, this development created a vicious circle. The rationalization of meat production made meat cheaper and producer prices and profit margins went down. This forced the farmers to once again intensify production by any available means and by following the American patterns.

Nevertheless, some reservation was still expressed in regard to national peculiarities. Officials agreed that it would make sense to make use of the wonders of chemistry to increase animal production, but they also underlined the differences between the USA and Western Germany. Whereas American agriculture was highly mechanized, German agriculture was not. Thus, leading scientists stated: "It seems not very convincing, to underline the applications for approval with hints to the example of the USA, when most simple measures which are fulfilled by farmers there, should allegedly not be possible with us for technical reasons" (Kewitz 1967: 393). Although the development in production went in the American direction, the evaluation of the arguments for and against the use of antibiotics in animal medicine did not. At least during 
the 1950s and 1960s, German farms and herds were much smaller, which implied different production conditions. Finally, animal protection played an important and ever increasing role in Germany. Already the $19^{\text {th }}$ century had seen a lively debate on vivisection, and from the end of the $19^{\text {th }}$ century life reformists and vegetarians campaigned against eating meat and for animal welfare. The first Animal Protection Law (Tierschutzgesetz) was released in 1933 (Troehler/Maehle 1987, Arluke/Sax 1981, Heintz 2008, Eberstein 1993, Martin 1989). Research on the increased growth of animals on medicated feeds showed that antibiotics would only speed up growth under bad living circumstances and among animals living in old, dirty and infected stables (Haenel 1959). From the point of animal protection, the encouragement of such bad living conditions which were compensated for and made possible by antibiotics seemed undesirable. Some microbiologists simply declared that such living conditions were only common in the USA, but not in Germany. ${ }^{27}$

Given the fact of globalization and the intensification of international meat trading, transnational regulation seemed necessary. In 1958, the Commission Internationale des Industries Agricoles had judged that research results did not suffice to justify regulative measures. ${ }^{28}$ But in 1967 the European Economic Community-the precursor of the European Union-released the first drafts of regulations on feeds and the World Health Organisation and the Food and Agricultural Organisation began to take measures as well. ${ }^{29}$

First, antibiotics had been rated as totally harmless, because they were 'natural' products, which were also to be found in plants, for example. In a second phase, their risk as residues in foods was assessed. Accordingly, regulatory action treated them very much like drugs and chemical substances. Licensing procedures were introduced in order to exclude dangerous products. These measures required proof of the harmlessness of the substances used before they were admitted to the market. Moreover, they argued for a control of milk, eggs and meat products with regard to antibiotic residues. ${ }^{30}$ Maximum doses in the feed were defined and withdrawal periods before slaughter were fixed in order to reduce risk. All these measures followed the idea that antibiotics were a food contaminant. Although Japanese scientists had demonstrated the transfer of resistance from one strain of bacteria to another in 1959, it took quite a while for resistancies to be acknowledged as the real and central problem of antibiotics. After suitable examination methods for residues had been developed in 1971, regular control measures of samples of all slaughtered animals were introduced by the new Meat Inspection Law (Fleischbeschaugesetz) of 1974. ${ }^{31}$ While the English Swann Report from 1968 still rated it as low and quite safe, surveillance showed a significant overall increase of resistant strains and their uncontrolled spread since the late 1960s. This changed when it was revealed that regulations had not managed the residues content of foods: In 1972, 82.5 per cent of calves' meat, 15 per cent of pig meat and about 6 per cent of beef were tested positive for antibiotics. ${ }^{32}$ 
It was around this time that discussions and the number of publications in scientific and popular journals peaked. A series of articles on this topic appeared in the official journal of the Federal Health Office and the journal of the consumer associations. Moreover, on June 21st 1971 the influential journal Der SPIEGEL featured the headline Drugs in the Feed. Poison on the Table on its cover. Scientific experts now agreed that the real danger was not residues in foods, but resistancies against antibiotics. To an increasing degree, the veterinarian became the target of criticism. The immense profit interests of the meat industry and the role of vets within this system turned out to be the core problem. This situation contrasted sharply with the alleged functions of the vets in the food system, where their profession takes a central role not only in the control of foods, but even in the supervision of the market of veterinary drugs.

This meat industry used drugs as a production means and its lobby made sure that antibiotics were not mentioned in advertising. Given the fact of an almost saturated and stagnating meat-consumption market, quality and purity began to become interesting selling points. The farmer and sausage-producer Redlefsen began to work without antibiotics on his farm in the 1970s, improving the pigs' living conditions, for instance, by installing a heating system in their stables. He offered higher prices to farmers who delivered their pigs to his factory if they declared that they used no antibiotic feed additives or medicines. He advertised his products extensively under the name "Pure Tasters (Reinschmecker),"33 a name that recalled the term Feinschmecker, which means "gourmet" in German. At the same time, new steakhouses began their very successful career in Germany, promising only pure and healthy meat that was produced without any chemicals or antibiotics. ${ }^{34}$

This demonstrated that alternative, non-regulatory and market-driven solutions were possible; if the producer had not expected some profit from this, he would not have made these innovations. Ironically enough, it was his own professional association that hindered Redlefsen from further pursuing his marketing strategy of advertising his sausages as free of antibiotics. Although the Federal Association of the German Meat Product Association (Bundesverband der Deutschen Fleischwarenindustrie) claimed to push the policy of controlling the additives and antibiotics in meat, by asking for better food controls to improve food quality, it initiated a juridical interdiction against Redlefsen. On May 18, 1972, the court prohibited further advertisements that declared that his products were particularly pure and healthy because of the meat having been produced without antibiotics. The court gave several reasons for its decision. Firstly, it argued that science had not proven that breeding animals without antibiotics would produce better, tastier and healthier meat. Secondly, it said that competition law prohibited creating the impression that one product was healthier than another. Furthermore, it stated that the advertisement was misleading, as it created anxiety among the consumers, although a later passage of the judgement stated that consumers were already 
anxious because of press releases. ${ }^{35}$ The latter argument clearly referred to the Drug Advertising Laws, which prohibited the arousal of fears in order to better sell one's drugs (Article 11), ${ }^{36}$ but it also resonated with the doctors' critique of sensationalism and tales of atrocity.

Redlefsen obviously did not see any chance of warding off the attack. In August 1972, a press release from Redlefsen and the associations reported the out-of-court settlement of the conflict. The agreements included a number of obligations for Redlefsen, but none for the association. The firm wanted to stick to its production policy and was allowed to continue the production of the Reinschmecker and use this brand name, even though it had agreed to not use it as a quality description in advertising. ${ }^{37}$

Although activists like Horst Stern and journals like Der SPIEGEL campaigned against the practices of modern meat production and for biological farming, it still took a couple of years to get at least a picture of the dimensions of the illegal drug market. ${ }^{38}$ In fact, it took until 1972 for the use of tetracycline as a growth promoter to be strictly forbidden, for the standard test to become available and a concerted reform of the drug, the food and the feed law to be realized. ${ }^{39}$ But still, the new feed law of 1975 did not aim at abolishing antibiotics in animal feed or even reducing them in general. Instead, action was mainly targeted against misuse.

While not changing the general position of the veterinarian and his right to produce, sell and prescribe animal drugs, the law was targeted against illegal imports, the grey market, and the delivery of antibiotics to laypeople, technicians and advisers. It aimed to establish control organs, and to give these new bodies the organizational, scientific and financial means to exert effective control as well as to prosecute offenders (Brühann 1975a, b, Kaemmerer 1967). The result was that a clear line between food and drugs was drawn, that marketing medicated feed to farmers and other laypeople was forbidden, and that the possibility of buying medicated feeds with antibiotics directly was abolished. First and foremost, it was fixed that a drug is and stays a drug in any form, and that it has to pass the usual approval procedures and be prescribed by a veterinarian, who has to exert control over its application (Heuner 1974). These measures were aimed at human health. However, the main problem, the industrial production system of meat with the help of veterinarians willing to sell all kinds of drugs to the farmers, was left untouched. This allowed the replacement of the now-forbidden growth promoting substances by a prescription from a veterinarian, which was officially justified by therapeutic reasons. As has been demonstrated in great detail for the Danish case, this more than compensated for the decrease in the use of growth promoters (Cellesen 2002: 60).

The main problem with the effects of antibiotics was a lack of solid evidence and sales figures. This fuelled public distrust, but the pharmaceutical industry was not interested in publishing these figures and the government did 
not force them to do so. Even in 2001 the European Union had to ask its member states to collect statistical data on the amount of antibiotics consumed (de With 2004: 1987). It was not until 2003 that relevant data on the national German levels were made available through a veterinary panel of the Society for Consumer's Research (Gesellschaft für Konsumforschung). These efforts were then taken up at the European level. ${ }^{40}$

Remarkably, the amount of antibiotics in veterinary medicine and agriculture had already declined in the run-up to legislation. In fact, the food industry and agribusiness probably acted before the ban of antibiotics in animal food because they anticipated the possible negative effects of discussions in the public arena, which would be disadvantageous for their sales figures. The ban of all antibiotic promoters in Sweden obviously had no negative economic effects on the farmers, but it took a long time for this fact to be available and noticed. Even firms like Hertha, which had been at the forefront of the meat producer's front against Redlefsen in the 1970s, now turned to antibiotic-free production methods and advertised this widely.

It is worth noting that the use of antibiotics as drugs for treating human illnesses did not decline at all, despite all discussions about the danger of resistancies. Instead, the consumption of antibiotics went up from 4.5 to 5.2 doses per person from 1998 to 2005, that is by 16.6 per cent. Most remarkable is how much higher this figure is for children. The number of doses per child climbed from 6.7 to 8.1 doses per year, that is by 20.8 per cent. ${ }^{41}$ Considering this, the amount of energy that was and is spent on discussions about the use of antibiotics in veterinary medicine, agriculture and the food industry is as remarkable as the amount of pressure exerted on the entire food producing sector. Overall, it suggests different reasons for different decisions. Antibiotics were and are regarded and evaluated differently in the spheres of food production and medical treatment, although there is a clear trend in health policy to press for reducing agricultural uses of antibiotics for the sake of saving the indispensable drugs for medical treatment.

\section{Scandal as Usual? A Look at Recent Developments}

To sum up the developments analyzed above, we can state that antibiotics play an important role in the agro-industrial complex until today. Introduced as a cure for animal diseases, such as tuberculosis and brucellosis which may affect the consumer as well, they soon developed into a production means, which was used to increase output. Pharmaceutical enterprises marketed them aggressively to make use of overcapacities and to compensate the price reductions by extending the usage of antibiotics. A critical discussion on the possible hazards of antibiotics began from early on. Reports and statements on 
the extensive use of antibiotics and other drugs in the meat industry have repeatedly called for action. Nevertheless, this use was never scandalized like, for example, the use of hormones as growth promoters. Until today, reports repeat the very same arguments over and over again, ${ }^{42}$ while the industry answers by pointing to the pressure of competition in the production of foods of good quality at affordable prices. ${ }^{43}$

Still, the use of antibiotics is on the rise. Between 2003 and 2010 it boosted from 724 to 900 tons, while a large grey market for veterinary drugs and antibiotics still exists. Like in the 1970s, so-called 'motorway veterinarians' (Autobahntierärzte) cover a large area of some hundred square kilometers in which they dispense and distribute drugs to farmers without having seen and examined their animals at all. In other words, they deliver on demand and perhaps recommend the use of this and that drug, which they perhaps produce themselves. ${ }^{44}$ Progress seems limited to having better mapped the outline of and reasons for the problem. But even these changes came after much increased activity from the Federal Health Office and social groups like consumer organizations, ecological movements, animal protection associations and the German branch of Friends of the Earth (Bund für Umwelt- und Naturschutz Deutschland). These groups collected a large database and were able to build up some pressure (Birkel 2012a, b), especially by cooperating with influential political journals. Their activities were backed up by the growing impact of the green movement, which made sustainability an element of chic lifestyle and repeatedly pointed to the pollution of the surroundings of poultry farms with antibiotics as well as to the existence of resistant bacteria and the growing danger of MRSA. When finally prominent cooks with expensive restaurants today argue for the use of biological products, this definitively alters the image of the branch, whose members had formerly been depicted as social romanticists and unworldly illusionists.

Since the mid-1980s a market for organic, antibiotic-free meat has been successfully established by first movers like the producer organization $\mathrm{Neu}$ land which was founded in 1977 and does not use feeds with antibiotics at all. ${ }^{45}$ While sales figures for biologically produced meat increase, conditions in conventional meat production change. The Federal Chamber of the Veterinarians (Bundestierärztekammer) has published guidelines for the use of antibiotics, which limit the application of antibiotics and require careful laboratory tests which properly assess the kind of infective bacteria. ${ }^{46}$ Nowadays even the formerly sacrosanct professional position of the veterinarians and their role in the production system are critically discussed, and the question has been raised whether vets should give up their right to dispense drugs. These recent developments would hardly have been thinkable without the changes in consumer politics which, after BSE and other food scandals, finally put consumer protection above economic aspects. ${ }^{47}$ The question remains: why did these changes take so long? Why did consumers not lose their trust in 
the producers at all? Why were activists not able or willing to scandalize antibiotics as they did repeatedly with hormone-related food scandals (Spiekermann 2007, Gaudilliére 2010).

There are several answers to this finding. First, the situation is a result of history which has shaped the German food control system. Unni Kjaernes, Mark Harvey and Alan Warde have shown and explained strong paths of dependency in the development of food risk management (Kjaernes/Harvey/ Warde 2007). After all, such dependencies are strongly related to the way in which production has been organized. In the case of Germany, this involved close relations between state-funded food research institutions and industry. The food research institutes of today go back to professional institutes, which were taken over by the State during the National Socialist regime. Under this regime, the institutes were expected to help in reaching autarchy. In other words: They had to help to increase food production by almost any means. Strong continuities determined their involvement after 1945. Not a single director of one of these institutes was dismissed. Under the conditions of the post-war food scarcity, their main task remained to increase food production and to improve food quality (Thoms 2009, 2010a, b). Extremes like the person of Andreas Lembke show how close the links between drug production, food research and food production were in this situation. As shown above, Lembke was not only engaged in drug research, he also held a patent for an antibiotic and had opened a private research institute. At the same time, he held the director's post in the Federal Institute for Milk Research in Kiel, where he served as an expert for milk and dairy production. Together with his colleagues from similar institutes, he shaped part of the food production system. At the same time, he was among the experts who influenced part of the food control system. Like the other experts, he claimed to be a scientist, a role thought of as being scientifically impartial. On the other hand, his position in a state-run institute required him to not be involved in public discussions with his own scientific opinion. Consequently, there was no strong agency campaigning for transparency, so that dark secrets dominated, even more so as the governmental agencies were slow in collecting information on such basic problems like the consumption figures of antibiotics, the numbers of resistancies and the like.

It took until the late 1960 s or early 1970 s for new social forces with more critical views to emerge: forces, which Bildgårdt as well as Giddens have regarded as essential for creating trust in post-modern societies. Then, different voices on these issues joined a choir of critical voices, which finally became loud enough to make its point against the alliance between industry and the food experts from the Federal Food Institutes. Consumer organizations were interested in this topic, but not clear about their intentions.

This brings me to my second explanation of why it took so long to take measures against the extensive use of antibiotics in agriculture. A look into 


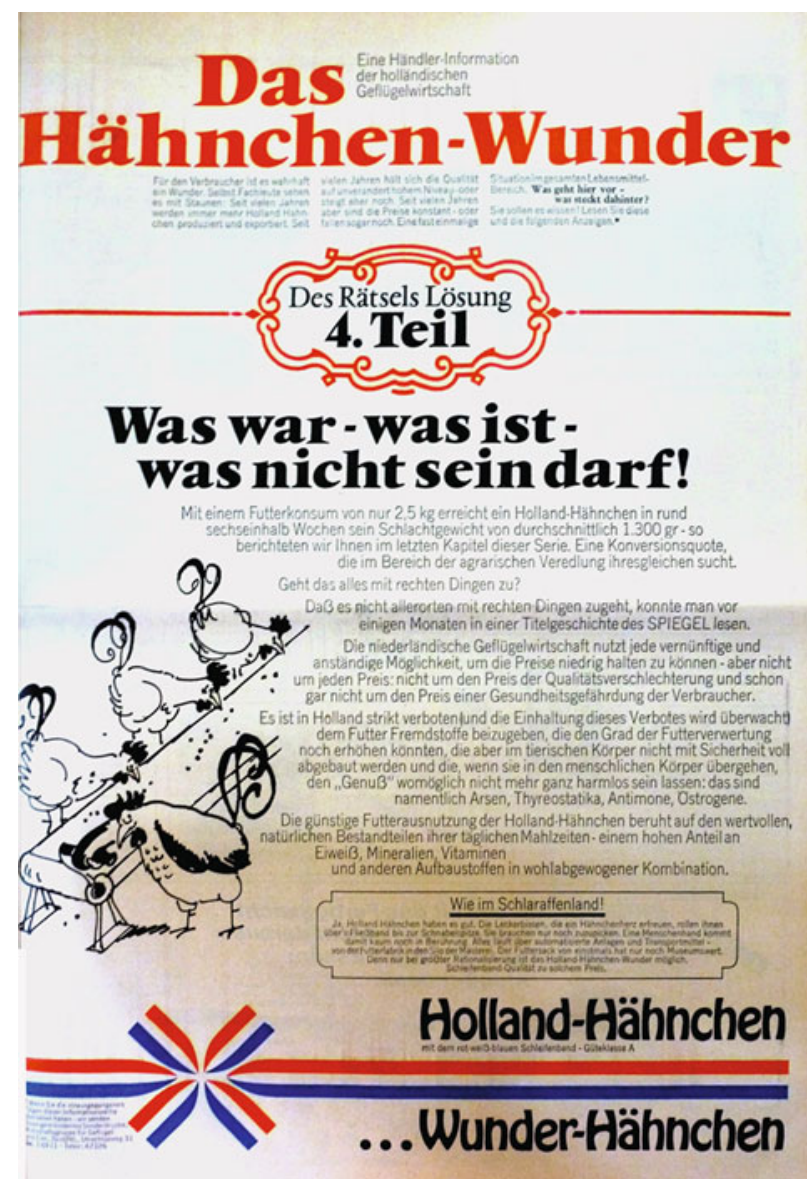

Fig. 2 Advertisement for Broilers out of a Series of $\mathrm{Six}^{48}$

consumer journals like, for example, the Verbraucherpolitische Korrespondenz reveals that consumer organizations were very much oriented towards low food prices during the 1950s and 1960s. Thus, they were very much in line with the policy in the state's research institutions. During these years, consumer journals were full with complaints about high food prices and demands to lower these prices. This is not to say that low food prices necessarily go handin-hand with low food quality. But in the context of industrial production systems, low prices are usually achieved by rationalization and industrialization. Inspired by the American model, German farmers thus used antibiotics as one instrument to rationalize their business. Cheap and abundant food was a strong element of the modern dream of prosperity of these years. The producers were very clear about this, at least the intensive advertising by poultry producers massively responded the critique of industrial production methods in the media (see Fig. 2). Farmers took pride in having been able to increase the 
average weight, shorten the feeding time and reduce the overall food consumption of the broilers. Their adverts played upon the ideas of modernity and progress, prosperity and abundance and equally resulted in regulation and control measures that made it possible to have high quality and low prices at the same time. As far as the steadily increasing sales figures show, this argumentation must have found some resonance among consumers, because even when public discussions on antibiotics reached a peak in 1971/72, the decline in meat consumption was only 1.7 kilogram per head per year, which is marginal. Furthermore, the consumption of poultry did not show any decline at all but continued to grow between 1971/72-1972/73.

My third argument is that antibiotics have in fact been seen as the signum of modernity. From their very beginning, they represented the triumph of modern science and still today promise a quick and safe cure of otherwise life-threatening diseases. There is hardly anyone, who has not taken an antibiotic at some point, usually in a health related situation with severe pain or high fever. People could hardly believe that these drugs, which they had experienced as helpful and harmless, should be harmful if used in animals, especially as they did not only cure diseases, but made farm animals grow quicker and look much better. Good looks and quick growth have always been identified as signs of health, whereas the risk of resistance was invisible, less concrete and far away. At least as long as enough new antibiotics were marketed, they saw no need for worries.

This was completely different with regard to hormones. Hormones are not so much used in acute illness, but to govern chronic illness or-in the case of contraceptives-are taken as lifestyle drugs (Malich 2012). The risk of hormones was very present in the public as, for example, the almost hysterical public discussion on the side-effects of the pill during the 1960s and 1970s documents (Silies 2010: 116-123). Moreover, there were real victims of hormones, as for example those women, who took DES (Diethylstilbestrol) during pregnancy to prevent miscarriage, premature labor and the like. Like their daughters, they have an increased risk of breast and vaginal cancer, while the daughters additionally have fertility problems. Due to their very active patient representations and lawsuits, they were very visible in the public. When the administration of these hormones to cattle was debated, there were strong public discussions, especially as the administration of the hormones to meat could be easily grasped from its pale color (Gaudilliére 2010).

Overall, this explains the different evaluation of hormones and antibiotics. Hormones were seen as dangerous substances. It was well-known that they could be transmitted to consumers, thus their use was rated as a harmful practice, which resulted from one-sided profit orientation and the conscious acceptance of the consequences. The situation of antibiotics was much more ambiguous: Their disadvantages were not so clear, especially as they were not visible at all and would be revealed only in the future. In the short run, they seemingly had more positive than negative effects. Even though the associated risks were acknowledged, the 
positive aspects and their characterization as 'wonder drugs' prevailed in public perception. As such, they were principally trusted as powerful medicines, especially since their medical use-in contrast to the very distant relations in globalized agriculture-took place in the context of the close and personal relations between patient and doctor. ${ }^{49}$ Medical doctors themselves strongly believed in the power of antibiotics and still today communicate this view to patients who long for a quick cure. Consequently, the prescription numbers of antibiotics still increase, especially among the most vulnerable population group, namely children. Here, it is the doctor as a person who guarantees the harmlessness of the drug and proves its reliability by prescribing it.

These three explanations for the long-lasting trust in antibiotics do not contradict each other. In fact, they touch upon different elements in the development of this drug class, each justifying the existence from another perspective. Against this background, it took quite a while until the critics managed to share their voices to make themselves heard. It took even longer until state institutions were willing to not only open their ears to these voices, but to act and to take measures to restrict the competence of the vets, to exert stricter control in the agro-industrial complex and to limit the constant expansion of the use of antibiotics. It will be interesting to see in how far this notion will finally result in real changes not only of attitudes, but even more of the factual use of antibiotics in agriculture.

\section{Endnotes}

1 Based on the number of relevant publications, the ongoing research activities peaked in the 1950s and 1960s. Until 1954, the number of isolated antibiotics amounted to 350, see Vogel 1954: 44. For the newly-identified substances, see: Pieroth 1992: 137, Wolf 1993. Patsch 1965, Ippen 1960 and Seidlen 1963 provide production figures.

2 Kraftfutter. Europäische Zeitschrift für die Futtermittel-und Getreidewirtschaft, 36 (1953): 19. All translations from German are mine.

3 In later years Patulin was banned from therapy because of its toxicity, see http://wikipedia.org/wiki/Patulin, last accessed: July 8, 2008.

4. For the figures, see: '1877-1967. 90 Jahre Milchforschung in Kiel' [Hildesheim] 1967: 7.

5 The appropriate description of Dubos' profession is somewhat questionable. Whereas Hotchkiss is said to have been a biochemist, Dubos is usually referred to as a microbiologist, who worked at the Rockefeller Institute in the field of medical microbiology. But such a classification may be misleading, as he earned his first degree in agronomy and in later years published many books on environmental questions, so that he may be called a universalist scientist. Biochemistry in general is not so much a discipline of its own, but bears a strong interdisciplinary character.

6 Streiflichter aus dem Commonwealth. Von unserem ständigen Fd-Mitarbeiter in London. Pharmazeutische Industrie, 18 (1956): 156-161, here 156.

7 Tagesnotizen. Münchener medizinische Wochenschrift, 100 (1959): 35.

8 See Endnote 5.

9 Vas/Kiss/Kiss 1967, Vonderbank 1956, Nisin, Lexikon der Ernährung in drei Bänden, Heidelberg/Berlin: Spektrum Akademischer Verlag, 2002, vol. 3:33.

10 Statistisches Jahrbuch über Ernährung und Forsten der Bundesrepublik 1990: 31, Carter 2006: 4-43. 
11 Die Freudenstädter Beschlüsse. Vitalstoffe 1 (1956): 3-7; Melzer 2003: 305-316.

12 Beschlüsse und Empfehlungen des 3. Internationalen Vitalstoff- und ErnährungsKonvents in Stuttgart-Bad Cannstatt. Vitalstoffe, 3 (1957): 119-124, here 120.

13 Kommentar. Schutz vor Geflügelfleisch mit gesundheitsschädlichen Zusätzen. Verbraucherpolitische Korrespondenz, 10(1963), No. 17, June 15, 3-4.

14 Gift in der Nahrung, Ein SPIEGEL-Gespräch mit dem Leiter der "Deutschen Forschungsanstalt für Lebensmittelchemie, Professor S. Walter Souci”. Der SPIEGEL, no. 45, January 5, 1958: 36-49, here 37.

15 Ibid.

16 Fortentwicklung des Lebensmittelrechts. Deutsches Ärzteblatt, 45 (1960): 827-828, Verordnungen zum Lebensmittelgesetz, 1959: 93.

17 Verordnungen zum Lebensmittelgesetz. Ärztliche Mitteilungen, 57 (1959): 1512-1514, ibid. 58 (1960): 92-95, 134-140, 192-185, 265-271, 483-490, 537-540, 611-613, $782-785$.

18 Antibiotica zu Futtermitteln. Deutsche Lebensmittel-Rundschau, 55 (1959): 264.

19 Spezielles Antibiotikum für die Tierernährung. Deutsches Tierärzteblatt, 66 (1969), 31-41.

20 Antibiotika-Problem. Die Fleischwirtschaft, 53 (1973): 823, Keine Antibiotika im Tierfutter. AGV für Verbot gesundheitsschädlicher Zusatzstoffe. Verbraucherpolitische Korrespondenz, 12 (1965), No. 3, January 25: 8-10.

21 For the regulation of feeds, see: http://ps4.rkwsued.de/filestore/27/93/916a30a 5-501e-4512-9820-5f323d2e72d7-web.pdf; http://www.dlg.org/kodex_mischfutter.html, [last accessed: May 15 2012].

22 Bundesanzeiger, November 2, 1951:213.

23 Grossklaus 1971: 40, see also Probleme der Arzneimittelanwendung am Tier. Bundesgesundheitsblatt, 13 (1971): 129-131.

24 Statistisches Jahrbuch über Ernährung und Forsten der Bundesrepublik 1972: 118, ibid. 1990: 387.

25 http://www.phw-gruppe.de/phw-historie.html, [last accessed May 25 2012].

26 Statistisches Jahrbuch über Ernährung und Forsten der Bundesrepublik 1963: 133, ibid. 1972: 118.

27 Antibiotika-Fütterung ohne Gefahr für Mensch und Tier. Deutsche tierärztliche Wochenschrift, 63 (1956): 158.

28 Antibiotika in Lebensmitteln. Bundesgesundheitsblatt, 2 (1959): 14.

29 Verwendung von Antibiotika für die Tierernährung. Pharmazeutische Industrie, 28 (1967): 336-337; Zusatzstoffe in der Tierernährung. Deutsches Ärzteblatt, 68 (1971): 1109.

30 Langfristige nutritive Anwendung von Antibiotika in der Tierernährung. Bundesgesundheitsblatt, 6 (1963): 145.

31 Rückstandsuntersuchungen im Rahmen der Fleischbeschau. Bundesgesundheitsblatt, 16 (1974): 107-108.

32 Rein oder nicht rein? Der SPIEGEL, No. 25, June 12, 1972: 57, see also Horn und Knochen. Der SPIEGEL, No. 46, November 8, 1971, 67-68.

33 Nun doch Reinschmecker! Lebensmittelzeitung, No. 25, June 23 1972: 4. Reinschmecker. Der SPIEGEL, No. 11, March 6 1972: 85.

34 Der SPIEGEL, No. 43, October 16, 1972: 88-90.

35 Die Urteilsbegründung im Falle Redlefsen. Verbraucher nicht gefragt. Lebensmittelzeitung, No. 20, May 19, 1972: 32.

36 http://www.gesetze-im-internet.de/heilmwerbg/index.html [last accessed: May 25, 2012].

37 Fleischwarenindustrie drängt auf wirksame Fleischkontrolle. Die Fleischwirtschaft, 52 (1972): 972.

38 Wenn Sie nicht fressen, spritze ich selbst. Der SPIEGEL, No. 26, June 26, 1971: 46-62.

39 Hemmstoff-Test geeignet! AGV: Baldigste Einführung notwendig. Verbraucherpolitische Korrespondenz, 12 (1972), No. 43, October 24: 4-5.

40 Stellungnahme des Wirtschafts- und Sozialausschusses zum Thema Antibiotikaresistenz eine Bedrohung der Volksgesundheit., Amtsblatt der EU, 1988, no. C 407: 7, Eine Strategie gegen die mikrobiologische Bedrohung. Amtsblatt EU N.C., 1999. 195:13, Mitteilung der Kommission über eine Strategie der Gemeinschaft zur Bekämpfung der Resistenz gegen Antimikrobielle Mittel vom 20. Juni 2001. Kommission der Europäischen Gemeinschaften: 
333 [http://eur-lex.europa.eu/LexUriServ/LexUriServ.do?uri=COM:2001:0333:FIN:DE: PDF, last accessed: June 6, 2012], Wrede 2004.

41 Arzneimittelmarkt-News des Wissenschaftlichen Institutes der AOK, February 2007 [http://wido.de/fileadmin/wido/downloads/pdf_arzneimittelwido_arz_gamsi_ammnews_ 0207.pdf, last accessed: February 21, 2007].

42 Antibiotika bleiben unverzichtbar, Bundesverband für Tiergesundheit Spezial, No. 55, February 52012 [available under: http://www.bft-online.de/newsletter, last accessed: May 26, 2012].

43 Ibid.

44. Dilloo 2001, Die leiden alle an Gedächnisschwund. Vertriebswege auf dem grauen und schwarzen Markt für Tierarzneimittel, Der SPIEGEL, No. 44, October 27, 1980: 119-126.

45 http://www.neuland-fleisch.de/verein/geschichte.html [last accessed: May 25, 2012].

46 Bundestierärztekammer/Arbeitsgemeinschaft der Leitenden Veterinärbeamten (2012). Leitlinien für den sorgfältigen Umgang mit antimikrobiell wirksamen Tierarzneimitteln, http://www.ktn.gv.at/22027_DE-Information-Antibiotikaleitlinien, [last accessed: April $15,2010]$.

47 Bundestierärztekammer 2012. Press Factsheet from 26 January 2012 on: „Arzneimittel und Antibiotika in der Nutztierhaltung", http://www.bundestieraerztekammer. de/downloads/btk/presse/aktuell/zusammenfassung-2012-01-27.pdf [last accessed: April 24, 2012].

48 Lebensmittelzeitung 1972, unpag.

49 Doctors are among the most trusted professionals, at least according to the yearly investigations of the Reader's Digest. Although doctors have lost some of the people's trust, they rank fifth in the hierarchy of trustworthy people [http://www.rp-online.de/ wirtschaft/beruf/die-vertrauenswuerdigsten-berufe-2012-1.2396998, last accessed: May 25, 2012].

\section{References}

Adams, David P., ed., 1991. "The Greatest Good to the Greatest Number”. Penicillin Rationing on the American Home Front, 1940-1945. Frankfurt a. M.: Lang.

Arluke, Arnold/Sax, Borias 1981. Understanding Animal Protection. Anthrozoös, 5, 6-31.

Atkins, Peter J., 1992. White Poison? The Social Consequences of Milk Consumption 1850-1930. Social History of Medicine, 5, 207-227.

Atkins, Peter J., 2000. Milk Consumption and Tuberculosis in Britain, 1850-1950. In: Alexander Fenton, ed., Order and Disorder. The Health Implications of Eating and Drinking in the Nineteenth and Twentieth Centuries, Edinburgh: Tuckwell, 83-95.

Bär, F., 1963. Tierarzneimittel und Aufzuchtmittel in der landwirtschaftlichen Praxis. Gesundheitliche Erwägungen zum Schutze des Konsumenten bei der Anwendung von Tierarzneimitteln und Aufzuchtmitteln in der landwirtschaftlichen Praxis. Medizin und Ernährung, 4, 67-70, 94-99, 122-127.

Barke, August, 1954. Der Verkehr mit antibiotikahaltigen Arzneimitteln zum Gebrauch für Tiere, Deutsche tierärztliche Wochenschrift, 61, 55-57.

Bazala, V., 1957. Antibiotica als Krankheitsursache. Vitalstoffe, 2, 132-34, 139.

Behm, G./Jäger, G., 1955. Möglichkeiten des Ersatzes tierischer Eiweißstoffe durch pflanzliche bei der Ernährung des Schweines. Archiv für Tierernährung, 5, 288-328.

Berger, Silvia, 2009. Bakterien in Krieg und Frieden. Eine Geschichte der medizinischen Bakteriologie in Deutschland 1890-1933, Göttingen: Wallstein Verlag.

Bildgårdt, Torbjörn, 2008. Trust in Food in Modern and Late-Modern Societies. Social Science Information, 47, 99-127.

Birkel, Kathrin, 2012a. BUND Hintergrundinformationen zu Antibiotikaeinsatz und Resistenzbildung in der Intensivtierhaltung [http://www.bund.net/fileadmin/bundnet/pdfs/ landwirtschaft/20120108_landwirtschaft_antibiotika_intensivhaltung_hintergrund.pdf, last accessed: April 29, 2012]. 
Birkel, Kathrin, 2012b. Analyse von Fleischproben auf MRSA und ESBL-produzierende Keime Fragen und Antworten [http://www.nnz-online.de/_daten/mm_objekte/2012/01/135782_ 0109_18440545.pdf, last accessed: April 29, 2012].

Bjarnar, Ove/Kipping, Matthias, 1998. The Americanisation of European Business. The Marshall Plan and the Transfer of US Management Models. London: Routledge.

Boyd, William, 2001. Making Meat. Science, Technology and American Poultry Production, Technology and Culture, 42, 631-664.

Bruegel, Martin/Stanziani, Alessandro, eds. 2004. La Securité alimentaire entre santé et marché, Revue d'histoire Moderne et Contemporaine, special issue, 51, No. 3.

Brombach, Christine, 2000. Ernährungsverhalten im Lebenslauf von Frauen über 65 Jahren. Eine qualitativ biographische Untersuchung, Gießen: Fachverlag Köhler.

Brüggemann, Johannes, 1954/1955. Die Verwendung von Antibioticis in der Ernährung unserer landwirtschaftlichen Nutztiere. Archiv für Tierernährung, 4, 71-75.

Brüggemann, Johannes, 1957. Über die Anwendung der Antibiotika in der Tierernährung. Deutsche tierärztliche Wochenschrift, 62, 14-16.

Brühann, Wilfried, 1971. Probleme der Arzneimittelanwendung am Tier. Deutsches Tierärzteblatt, $19,167-170$.

Brühann, Wilfried, 1975a. Betr. Arzneimittelgesetz, hier: Fütterungsarzneimittel. Deutsches Tierärzteblatt, 17, 366.

Brühann, Wilfried, 1975b. Abgabe von Arzneimitteln durch Tierärzte an Halter der von ihnen behandelten Tiere. Deutsches Tierärzteblatt, 23, 367-372.

Bud, Robert, 1994. The Uses of Life. A History of Biotechnology. Cambridge: Cambridge University Press.

Bud, Robert, 2007. Penicillin. Triumph and Tragedy. Oxford: Oxford University Press.

Carter, Susan (ed.) 2006. Historical Statistics of the United States. Cambridge: Cambridge 1085 University Press, vol. 4.

Cellesen, Jes, 2002. Effects of Termination of AGP-use on Pig Welfare and Productivity. In: Beyond Antimicrobial Growth Promoters in Food Animal Production. Papers from the Workshop at the Research Centre Foulum 6-7 November 2002, 2004. DIAS report Animal Husbandry, 57 [http://www.who.int/gfn/links/en/FoulumWorkingPapers.pdf\#page=43, last accessed: April 15, 2010].

Cremer, H[ans] D]iedrich], 1957. Zur Frage der Fremdstoffe in der Nahrung. Hippokrates, 511-514.

Cremer, Hans Diedrich, 1962. Freedom-From-Hunger-Campaign, eine weltumfassende Aktion der FAO. In: Johann Carl Somogyi, ed., Ernährungswissenschaft im Dienste der Entwicklungsländer. Basel: Karger, 252-260.

Dilloo, Rüdiger, 2001. Die dunklen Seiten eines Traumberufs. Mastskandal und Rinderwahn haben die Veterinäre in Verruf gebracht. Ein Report aus Stall und Kleintierpraxis. Die Zeit, No. 7, 8 February 2001, online under: [http://www.zeit.de/2001/07/Die_dunklen_Seiten_eines_ Traumberufs, last accessed: April 22, 2012].

Drews, Joachim, 2002. Die Gleichschaltung im Stullenverzehr. Ernährungspsychologie im Dritten Reich - zwei Fundstücke. Werkstatt Geschichte, 32, 82-92.

Dubos, René/Hotchkiss, Rolin, 1940a. Fractionation of the Bactericidal Agent from Cultures of a Soil Bacillus. Journal of Biological Chemistry, 132, 791-792.

Dubos, René/Hotchkiss, Rolin, 1940b. Chemical Properties of Bactericidal Substances Isolated from Cultures of a Soil Bacillus. Journal of Biological Chemistry, 132, 793-794.

Eberstein, Winfried C. J., 1993. Das Tierschutzrecht bis zum Erlaß des Reichs-Tierschutzgesetzes vom 24. November 1933. Frankfurt a. M.: Lang.

Eichholtz, Fritz, 1956. Die toxische Gesamtsituation auf dem Gebiet der menschlichen Ernährung. Umrisse einer unbekannten Wissenschaft. Berlin: Springer.

Eichholtz, Fritz, 1958. Vom Streit der Gelehrten. Dem Deutschen Arzt und dem deutschen Konsumenten. Karlsruhe: Braun.

Entel, H. J., 1970. Rechtliche Grundlagen für die Zulassung von Wirkstoffen in der Tierernährung. Deutsches Tierärzteblatt, 18, 44-48.

Fischler, Claude, 2002. Food Selection and Risk Perception. In: Harvey Anderson, John Blundell and Matty Chiva, eds., Food Selection. From Genes to Culture. Levallois-Perrt: Danone. 135-151. 
Forth, Wolfgang/Gericke, Dietmar/Schenck, Ernst-Günther, 1997. Von Menschen und Pilzen. Zur Geschichte der Penicillin-Produktion im ehemaligen Deutschen Reich und in der Zeit der Besatzung nach 1945. München: Zuckschwerdt.

Freerksen, Enno 1956. Die Bedeutung der Antibitiocafütterung und Lebensmittelfrischhaltung für den Menschen. In: Die Bedeutung der Antibiotica in der Tierernährung und Lebensmittelhygiene unter besonderer Berücksichtigung von Aureomycin. Internationales Symposium 15.-17. November 1956 in Wien. Wien/Aulendorf: Cantor, 149-158.

Gaudilliére, Jean-Paul, 2007. The Farm and the Clinic. An Inqiry into the Making of our Biotechnological Modernity. Studies in the History of Biological and Biomedical Sciences, 38, 521-529.

Gaudilliére, Jean-Paul 2010. Food, Drug and Consumer Regulation. The "Meat, DES and Cancer" Debate in the United States. In: David Cantor, Christian Bonah and Matthias Dörries, eds., Meat, Medicine and Human Health in the Twentieth Century, London: Pickering \& Chattoo, 179-202.

Giddens, Anthony 1995. Konsequenzen der Moderne, 2nd ed., Frankfurt a. M.: Suhrkamp.

Graffmann-Weschke, Katharina, 1999. Lydia Rabinowitsch-Kempner (1871-1935). Leben und Werk einer der führenden Persönlichkeiten der Tuberkuloseforschung am Anfang des 20. Jahrhunderts. Herdecke: GCA-Verlag.

Grossklaus, [Dieter], 1967. Antibiotikarückstände in der Trinkmilch. Deutsche tierärztliche Wochenschrift, 74, 462-465.

Grossklaus, Dieter, 1971: Rückstandsprobleme vom Nutztier bis zum Lebensmittel. Bundesgesundheitsblatt, 14: 37-43.

Haenel, Helmut, 1959. Zum Wirkungsmechanismus der Antibiotika in der Tierernährung. Ernährungsforschung, 4, 500-513.

Harrison, Ruth, 1965. Tiermaschinen: Die neuen landwirtschaftlichen Fabrikbetriebe. München: Biederstein Verlag [Original: Animal Machines, 1964].

Hegener, Hermann, 1953. Antibiotica und Vitamin B 12 in der Schweinemast, Diss. Kiel, Bad Godesberg Hauswirtschaftlicher Auswertungs- und Informationsdienst, [=Schriftenreihe des AID/Auswertungs- und Informationsdienst, 62].

Heintz, Daniel, 2008. Tierschutz im Dritten Reich. Im neuen Reich darf es keine Tierquälerei mehr geben. Mülheim: Land- und Hauswirtschaftlicher Auswertungs- und Informationsdienst e.V.

Heuner, F., 1974. Erläuterungen zum Arzneimittel-Änderungsgesetz vom 5. Juni 1974. Deutsches Tierärzteblatt, 22, 590-596.

Höfer, Hugo/Juckenack, Adolf/Nüse, Karl-Heinz, 1961. Deutsches Lebensmittelrecht, vol. 1, 4th ed., Berlin: Heymann.

Ippen, H[elmut], 1960. Neues aus den USA. Pharmazeutische Industrie, 22, 119.

Jacobeit, Wolfgang/Kopke, Christoph, 1999. Die biologisch-dynamische Wirtschaftsweise im KZ. Die Güter der "Deutschen Versuchsanstalt für Ernährung und Verpflegung" der SS von 1939 bis 1945. Berlin: trafo-Verlag.

Jaenicke, Lothar, 2009. Lydia Rabinowitsch-Kempner. biospektrum, 15, 345-347.

Jukes, T[homas] H. E. L. R. et al., 1950. Growth-promoting Effect of Aureomycin on Pigs. Archive of Biochemistry, 29, 452.

Kaemmerer, K., 1967. Übersicht zum Gesetz über die Werbung auf dem Gebiet des Heilwesens aus tierärztlicher Sicht, Deutsches Tierärzteblatt, 15, 51.

Kewitz, 1967. Welche Anforderungen müssen an die Herstellung von Arzneimitteln - gebunden an Futtermittel als Trägestoff - gestellt werden? Deutsches Tierärzteblatt, 15, 384-394.

Kjaernes, Unni/Harvey, Mark/Warde, Alan, 2007. Trust in Food. A Comparative and Institutional Analysis. New York: Palgrave Macmillan.

Knothe, Hans, 1967. Antibiotische Stoffe in der Tierhaltung und mögliche Rückwirkungen auf den Menschen im Hinblick auf Allergie und Bakterienresistenz. Deutsches Tierärzteblatt, 1, special no., 26-29.

Kraut, Heinrich, ed., 1959. Beiträge zum Antibiotika- und Eiweissproblem, Darmstadt: Steinkopff.

Krige, John, 2006. American Hegemony and the Postwar Reconstruction of Science in Europe, Cambridge, Mass.: MIT Press.

Lang, Konrad, 1957. Behandlung von Lebensmitteln mit chemischen Zusätzen. Deutsche Medizinische Wochenschrift, 82, 140-141.

Lembke, Andreas, 1940. Über die Bedeutung von Oospora Wallroth sem. Sacc. für die Reifung der Sauermilchkäse. Die Käse-Industrie, 13, 82-84, 93-95. 
Lembke, Andreas, 1943. Ergebnisse der theoretischen und angewandten Mikrobiologie. Neudamm: Neumann.

Lembke, Andreas/Ruska, H./Christophersen, J., 1940. Vergleichende mikroskopische und übermikroskopische Beobachtungen an den Erregern der Tuberkulose, I. Mitteilung: Der Stand der morphologischen Erforschung des Tuberkuloseerregers. Klinische Wochenschrift, $19,217-220$.

Linneweh, Friedrich, 1949. Klinische Erfahrungen mit streptomycinkonservierter Frauenmilch. Medizinische Klinik, 44, 666-670.

Lüers, Heinrich, 1949. Die Hefe. Eine Gesamt-Literaturübersicht mit einführendem Text. Nürnberg: H. Carl.

Luhmann, Niklas, 1968. Vertrauen. Ein Mechanismus der Reduktion sozialer Komplexität. Stuttgart: Enke.

Luther, Herbert G 1953. Antibiotika in Mischfuttermitteln, Kraftfutter. Europäische Zeitschrift für die Futtermittel- und Getreidewirtschaft, 36: 6-7.

Malich, Lisa 2012. Vom Mittel der Familienplanung zum differenzierenden Lifestyle-Präparat. Bilder der Pille und ihrer Konsumentin in gynäkologischen Werbeanzeigen seit den 1960er Jahren in der BRD und Frankreich. NTM. Zeitschrift für Geschichte der Wissenschaften, Technik und Medizin, 20, 1-30.

Malycha, Andreas/Thoms, Ulrike, 2009. Aufbruch in eine neue Zukunft? Biowissenschaftliche Prognosen in der DDR und der Bundesrepublik in den 1960er und 1970er Jahren. In: Heinrich Hartmann and Jakob Vogel, eds., Zukunftswissen. Prognosen in Wirtschaft, Politik und Gesellschaft seit 1900. Frankfurt a. M./New York: Campus, 107-136.

Marschall, Luitgard, 2000. Im Schatten der chemischen Synthese. Industrielle Biotechnologie in Deutschland 1900-1970. Frankfurt a. M./New York: Campus.

Martin, Madeleine, 1989. Die Entwicklung des Tierschutzes und seiner Organisationen in der Bundesrepublik Deutschland, der Deutschen Demokratischen Republik und dem deutschsprachigen Ausland, PhDissertation, Freie Universität Berlin.

Meadows, Donella H., 1972. The Limits to Growth. A Report for the Club of Rome's Project on the Predicament of Mankind, New York: Universe Books.

Melzer, Jörg, 2003. Vollwerternährung. Diätetik. Naturheilkunde, Nationalsozialismus, sozialer Anspruch, Stuttgart: Steiner.

Mergenthaler, E., 1955. Auszug aus Mitteilung 1 der „Kommission zur Prüfung der Lebensmittelkonservierung” der Deutschen Forschungsgemeinschaft. Zeitschrift für Untersuchung der Nahrungs- und Genussmittel, 102, 185-186.

Moore, P. R. et al., 1946. Use of Sulfasuxidine, Strepothricin, and Streptomycin in Nutritional Studies with the Chick. Journal of Biological Chemistry, 165, 437.

Mossel, A. A., 1955. Die Haltbarmachung von Lebensmitteln auf chemischem Wege mit besonderer Berücksichtigung toxikologischer Fragen. Zeitschrift für Lebensmitteluntersuchung, 102, 254-268.

Münzberg, Helmut, 1954. DLG-Kraftfutter-Standards 1954/55. Mitteilungen der Deutschen Landwirtschafts-Gesellschaft, 69, 436.

Nolan, Mary, 1994. Visions of Modernity. American Business and the Modernization of Germany. Oxford/New York: Oxford University Press.

Orland, Barbara, 2003. Cow's Milk and Human Disease. Bovine Tuberculosis and the Difficulties Involved in Combating Animal Diseases. Food and History, 1, 170-202.

Partmann, W[alter], 1954. Neuere Ergebnisse zur Wirksamkeit von bactericiden Zusätzen für die Fischbeeisung. Fette und Seifen, 56, 505-512.

Partmann, W[alter], 1957. Antibiotika in der Lebensmittelkonservierung. Zeitschrift für Lebensmitteluntersuchung und -forschung, 106, 210-227.

Patsch, Rolf, 1965. Antibiotika-Ratgeber für die medizinische Praxis. Jena: Fischer.

Pearson, D., 1962. Food Additives and Meat Hygiene. Nature, 166, 727-727.

Pieroth, Ingrid, 1992. Penicillinherstellung. Von den Anfängen bis zur Großproduktion. Stuttgart: Wissenschaftliche Verlags-Gesellschaft.

Poutrus, Patrice G., 2002. Die Erfindung des Goldbroilers. Über den Zusammenhang zwischen Herrschaftssicherung und Konsumentwicklung in der DDR. Köln: Böhlau.

Rutschky, Michael, 2004. Wie wir Amerikaner wurden. Eine deutsche Entwicklungsgeschichte, München: Ullstein. 
Sarasin, Philipp/Berger, Silvia/Haenseler, Marianne/Spörry, Miriam, eds., 2006. Bakteriologie und Moderne. Studien zur Biopolitik des Unsichtbaren, Frankfurt a.M.: Suhrkamp.

Scholliers, Peter, 2008. Defining Food Risks and Food Anxieties throughout History. Appetite, 51, $3-6$.

Schultz, 1967. Die derzeitige rechtliche und wirtschaftliche Abgrenzung zwischen Arzneimitteln und Futtermitteln in ihrer Bedeutung für Tierarzt und Tierbesitzer. Deutsche tierärztliche Wochenschrift, 74, 462-465.

Schweigart, [Adalbert], 1956. Zur Einführung. Vitalstoffe, 1: 1-2.

Seidlen, Rudolf, 1963. Neues aus den USA. Pharmazeutische Industrie, 25, 760-761.

Shama, Gilbert/Reinarz, Jonathan, 2002. Allied Intelligence Reports on Wartime German Penicillin Research and Production. Historical Studies in the Physical and Biological Sciences, 32, 347-367.

Sinell, Hans-J., 1967. Auswirkung der Arzneimittelanwendung auf die Lebensmittel- und Milchhygiene. Deutsches Tierärzteblatt, 64, special no., 30-32.

Silies, Eva-Maria, 2010. Liebe, Lust und Last. Die Pille als weibliche Generationserfahrung in der Bundesrepublik 1960-1980. Göttingen: Wallstein.

Sperling, Frank, 2011. „Kampf dem Verderb mit allen Mitteln?”? Der Umgang mit ernährungsbezogenen Gesundheitsrisiken im „Dritten Reich” am Beispiel der chemischen Lebensmittelkonservierung, Stuttgart: Deutscher Apotheker Verlag.

Spiekermann, Uwe, 1993. Milchkleinhandel im Wandel. Eine Fallstudie zu München, 1840-1913. Scripta Mercaturae, 27, 91-144.

Spiekermann, Uwe, 2001. Der Naturwissenschaftler als Kulturwissenschaftler. In: Gerhard Neumann and Alois Wierlacher, eds., Essen und Lebensqualität. Natur- und Kulturwissenschaften im Gespräch. Frankfurt a. M./New York: Campus, 247-274.

Spiekermann, Uwe, 2004. Die Normalität des (Lebensmittel-)Skandals. Risikowahrnehmungen und Handlungsfolgen im 20. Jahrhundert, Hauswirtschaft und Wissenschaft, 52, 60-69.

Spiekermann, Uwe, 2007. Hormonskandale. In: Skandale in Deutschland nach 1945, ed. by Stiftung Haus der Geschichte der Bundesrepublik Deutschland, Bielefeld: Kerber, 104-113.

Staples, Amy L. S., 2003. To Win the Peace: The Food and Agriculture Organization, Sir John Boyd Orr, and the World Food Board Proposals. Peace E Change, 28, 495-523.

Stoff, Heiko, 2009. Hexa-Sabbat. Fremdstoffe und Vitalstoffe, Experten und der kritische Verbraucher in der BRD der 1950er und 1960er Jahre. NTM. Zeitschrift für Geschichte der Wissenschaften, Technik und Medizin, 17, 55-83.

Stokstad, E. L. Robert/Jukes, Thomas H., 1949. Informal Poultry Nutrition Conference Federation Meetings 1949.

Stokstad, E. L. Robert, 1953. Antibiotics in Animal Nutrition. Antibiotics and Chemotherapy, 3, 434-441.

Tangl, Harald, 1959. Die Rolle der Vitamine, Hormone und Antibiotika in der Tierzucht. Budapest: Akadémiai Kiadó.

Teuber, Michael/von Milczewski, Karl-Ernst, 1990. 100 Jahre Mikrobiologie an der Bundesanstalt für Milchforschung in Kiel 1889-1989. Kiel: Institut für Mikrobiologie der Bundesanstalt für Milchforschung.

Teuteberg, Hans J., 1986. Der Verzehr von Nahrungsmitteln per Kopf und Jahr seit Beginn der Industrialisierung (1850-1975). Versuch einer quantitativen Langzeitstudie. In: Hans J. Teuteberg and Günter Wiegelmann, eds., Unsere tägliche Kost. Geschichte und regionale Prägung, Münster: Coppenrath, 225-279.

Thoms, Ulrike, 2006, Einbruch, Aufbruch, Durchbruch? Strukturen und Netzwerke der deutschen Ernährungsforschung vor und nach 1945. In: Rüdiger vom Bruch, Uta Gerhardt and Aleksanda Pawliczek eds., Kontinuitäten und Diskontinuitäten in der Wissenschaftsgeschichte, Stuttgart: Steiner, 111-130.

Thoms, Ulrike, 2009. Vom Nutzen der Wissenschaft für den Staat. Ressortforschung im Bereich der Milchwirtschaft. In: Christine Pieper and Frank Uekötter, eds., Vom Nutzen der Wissenschaft für den Staat. Beiträge zu einer prekären Beziehung. Stuttgart: Steiner, 115-141.

Thoms, Ulrike, 2010a. Ressortforschung und Wissenschaft im 20. Jahrhundert. Das Beispiel der Reichs- und Bundesanstalten im Bereich der Ernährung. In: Axel Hüntelmann and Michael Schneider, eds., Jenseits von Humboldt. Wissenschaft im Staat 1850-1990. Frankfurt/New York: Campus, 27-48. 
Thoms, Ulrike, 2010b. Vegetarianism in Germany and its Fate in the "Third Reich". In: David Cantor, Christian Bonah and Matthias Dörries eds., Meat, Medicine and Human Health in the Twentieth Century, London, Pickering \& Chattoo, 145-157.

Troehler, Ulrich/Maehle, Andreas, 1987. Anti-vivisection in Nineteenth Century Germany, Motives and Methods. In: Nicolas A. Rupke, ed., Vivisection in Historical Perspective. New York: Routledge, 149-187.

Uekötter, Frank, 2009. Apokalyptik als Profession? Ängste, Prognosen und die internationale Umweltbewegung. In: Heinrich Hartmann and Jakob Vogel, eds., Zukunftswissen. Prognosen in Wirtschaft, Politik und Gesellschaft seit 1900, Frankfurt a. M./New York: Campus, 284-300.

Vas, K./Kiss I./Kiss H. 1967. Über die Anwendung von Nisin zur Verkürzung der Wärmebehandlung bei der Sterilisierung von Grünerbsen. Zeitschrift für Lebensmitteluntersuchung und-forschung, 133, 141-144.

Vogel, Hans, 1954. Hemmstoffe. Heilstoffe. Einführung in die Lehre von den Antibiotica, Nürnberg: Carl.

Vogt, Annette, 1997. Der „Milch-Skandal” machte sie berühmt. Berlinische Monatsschrift, 7, no. 7, $32-36$

Vonderbank, Hermann, 1956. Die Antibiotika außer Penicillin. 3. Fortschrittsbericht, Ende 1949 bis Ende 1950, 1. Mitteilung. Arzneimittelforschung, 1, 82-89.

Waddington, Keir, 2010. Mad and Coughing Cows. Bovine Tuberculosis, BSE and Health in Twentieth Century Britain. In: David Cantor, Christian Bonah and Matthias Dörries, eds., Meat, Medicine and Human Health in the Twentieth Century, London: Pickering \& Chatoo, 159-178.

Weight, Ursula/Kramer R., 1968. Zur Zunahme der Antibiotikaresistenz bei Mastitiserregern. Deutsches Tierärzteblatt, 16, 167-622.

White-Stevens, Robert H., 1956. Die Anwendung von Aureomycin (Chlortetracyclin) zur Verlängerung der Haltbarkeit von Geflügel, Fleisch und Fisch. In: Die Bedeutung der Antibiotica in der Tierernährung und Lebensmittelhygiene unter besonderer Berücksichtigung von Aureomycin. Aulendorf: Editio Cantor, 104-122.

Wildt, Michael, 1994. Am Beginn der „Konsumgesellschaft”. Mangelerfahrung, Lebenshaltung, Wohlstandshoffnung. Westdeuschland in den fünfziger Jahren. Hamburg: Ergebnisse Verlag.

With, K. de, 2004. Antibiotikaverwendung im europäischen Vergleich. Deutsche Medizinische Wochenschrift, 129, 1987-1992.

Wolf, János, 1993. Strukturen in der Entstehung einer wissenschaftlich-technischen Revolution. Über die Diskontinuität zwischen Entdeckung und Revolution beim Auftauchen des Penicillins und der Antibiotika, Berlin: Wissenschaftszentrum Berlin, Veröffentlichungsreihe der Forschungsgruppe Gesundheitsrisiken und Präventionspolitik, Wissenschaftszentrum Berlin für Sozialforschung, 202.

Wolff, Gottfried, 1968. Ohnmacht unserer Gesundheitsbehörden. Lehren aus dem MTURindermastskandal. Deutsches Tierärzteblatt, 16, 404-409.

Wrede, Olaf, ed., 2004. Das europäische Futtermittelrecht unter dem Einfluss des Konzeptes der Lebensmittelsicherheit. Köln: Heymanns.

Zeitlin, Jonathan/Herrigel, Gary, 2000. Americanization and its Limits. Reworking US Technology and Management in Post-War Europe and Japan. Oxford/New York: Oxford University Press.

Zinzius, Joseph, 1954. Die Antibiotika und ihre Schattenseiten. Stuttgart: Hippokrates Verlag.

\section{Ulrike Thoms}

Institut für Geschichte der Medizin

Charité - Universitätsmedizin Berlin

Ziegelstr. 5-9

10117 Berlin

Germany

E-mail: ulrike.thoms@charite.de 